\title{
Effect of different sowing times and spacings on growth, yield and quality of water spinach (Ipomoea reptans Poir.) under terai region of West Bengal
}

\author{
R. K. Sarkar ${ }^{1}$, J. C. Jana and S. Datta*
}

Department of Vegetable and Spice Crops, Uttar Banga Krishi Viswavidyalaya, Pundibari, Cooch Behar-736165 (West Bengal), INDIA

${ }^{1}$ SMS, Darjeeling Krishi Vigyan Kendra, UBKV, Kalimgpong, Darjeeling (West Bengal), INDIA

*Corresponding author. E-mail: suchanddatta@gmail.com

Received: February 16, 2014 ; Revised received: August 08, 2014; Accepted: October 13, 2014

Abstract: An experiment was conducted to find out suitable sowing time and spacing as to increase the production of both green and seed yield and its quality of water spinach (Ipomoea reptans Poir.) during the year 2007-08 and 2008-09. The experiment was comprised of three sowing times $\left(1^{\text {st }}\right.$ week of May; $1^{\text {st }}$ week of June and $1^{\text {st }}$ week July) and three spacings $(30 \mathrm{~cm} \times 15 \mathrm{~cm} ; 30 \mathrm{~cm} \times 30 \mathrm{~cm}$ and $30 \mathrm{~cm} \times 45 \mathrm{~cm})$. It was found that early sowing on $1^{\text {st }}$ week of May and closest spacing of $30 \mathrm{~cm} \times 15 \mathrm{~cm}$ alone and their combination executed best results with respect to all parameters. The sowing on $1^{\text {st }}$ week of May with closest spacing of $30 \mathrm{~cm} \times 15 \mathrm{~cm}$ produced about 3.26 times higher green yield (18.83 t/ha). On the other hand, sowing on $1^{\text {st }}$ week of June with $30 \mathrm{~cm} \times 15 \mathrm{~cm}$ spacing contributed 52.95 percent higher seed yield $(0.78 \mathrm{t} / \mathrm{ha})$. All the seed quality testing parameters viz. shelling percentage (62.53), 1000 seed weight $(40.56 \mathrm{~g})$, germination percentage (82.40), seedling vigour index (5.38) and seedling growth rate $\left(0.091 \mathrm{~g} / \mathrm{plant} /\right.$ day) were observed to be highest in $1^{\text {st }}$ week of June with widest spacing of $30 \mathrm{~cm} \times 45 \mathrm{~cm}$. On economic point of view, the combination of $1^{\text {st }}$ week of May along with $30 \mathrm{~cm} \times 15 \mathrm{~cm}$ spacing was noticed to be superior amongst all other treatment combinations and that may be adopted for its commercial cultivation in medium to upland situation under terai region of West Bengal.

Keywords: Growth, Ipomoea reptans, Quality, Sowing time, Spacing, Water spinach

\section{INTRODUCTION}

Water spinach or water convolvulus or swamp cabbage (Ipomoea reptans Poir.) belongs to the family convolvulaceae is an under-exploited herbaceous perennial, aquatic and semi aquatic leafy vegetable of the tropics and subtropics. The edible portion contain up to $29 \%$ crude protein on a dry matter basis (Thacker, 1990). It is also rich sources of minerals and vitamins, being especially rich in vitamin $\mathrm{A}$, vitamin $\mathrm{B}_{1}$, vitamin $\mathrm{B}_{2}$ and vitamin $\mathrm{C}$ and in iron, zinc, copper and manganese (Sarkar, 2012). There are two main cultivar groups of var. aquatica and var. reptans. The first is an aquatic plant, propagated by cuttings and growing in the wild or cultivated in the fish ponds and water courses. The second is an upland vegetable, cultivated on dry or marshy land and propagated by seeds or cuttings (Palada and Crossman, 1998). A white flower is produced which matures into a four seeded pod. Flowering occurs under short day condition. But the cultivation of upland water spinach is limited due to non-availability of seeds to the farmers.Since, the cultivation of water spinach is not extended at commercial scale; most of the requirement for Indian kitchen is met through collection from wild water courses. Looking at the demand of this leafy vegetable considering the nutritional importance and also to conserve the natural resources and biodiversity, there is an urgent need to develop agro-techniques for enhances the commercial viability of this crop. The present study was therefore, undertaken to standardize the optimum sowing time and plant spacing for maximizing the biomass production as well as good quality seeds under rainfed terai region of West Bengal.

\section{MATERIALS AND METHODS}

The present experiment was conducted during kharif seasons of 2007-08 and 2008-09 at the Instructional Farm of Uttar Banga Krishi Viswavidyalaya in terai region of West Bengal. The experimental site was medium low, sandy loam in texture, acidic in nature and low fertility status. The climate of terai zone is sub-tropical humid in nature with distinctive characteristics of high rainfall, high humidity and a prolonged winter. The experiment was laid out in factorial randomized block design with three replications. The experiment was comprised of three sowing times $\left(\mathrm{P}_{1}=1^{\text {st }}\right.$ week of May; $\mathrm{P}_{2}=1^{\text {st }}$ week of June and $\mathrm{P}_{3}=1^{\text {st }}$ week July) and three levels of spacing $\left(S_{1}=30 \mathrm{~cm} \times 15 \mathrm{~cm} ; S_{2}=30 \mathrm{~cm} \times 30 \mathrm{~cm}\right.$ and 
$\mathrm{S}_{3}=30 \mathrm{~cm} \times 45 \mathrm{~cm}$ ). The sowing of seed was done directly in the main filed and plot size was $3.0 \mathrm{~m} \times 1.80$ $\mathrm{m}$. The crop was supplied with 20 tonnes well rotten farm yard manure per hectare along with $100 \mathrm{~kg} \mathrm{~N}, 60$ $\mathrm{kg} \mathrm{P}_{2} \mathrm{O}_{-5}$ and $80 \mathrm{~kg} \mathrm{~K} \mathrm{O}_{2} \mathrm{~kg}$ per hectare. All $\mathrm{P}, \mathrm{K}$ and $1 /{ }^{\text {th }} \mathrm{N}$ were drilled at the time of land preparation and another $3 / 4^{\text {th }}$ of $\mathrm{N}$ in three equal splits as top dressing. Harvesting of green leaves with tender stems was done by top shoot cutting of $25-30 \mathrm{~cm}$ length twigs leaving $10 \mathrm{~cm}$ above the ground. Thereafter, subsequent harvesting was done at 20 days interval. After 3 times harvesting of green twigs, the plants were left for seed production. Flowering generally starts when the day become shorter and average temperature gradually goes down from October and seed sets in December. Harvesting of fruits was done by picking with hands in the month of middle of February when fruits started showing signs of turning yellow colour. The harvested fruits were kept plot wise on threshing floor for few days for complete drying. Then threshing was done by rubbing the fruits with wooden stick on the floor. Seeds were cleaned and dried in well ventilated shady room for few days to reduce the moisture. The weight of the cleaned and dried seeds from each of the experimental plots as per treatment schedule was recorded in kilograms for computation of yield data. Seed yield per plot was converted to tonnes per hectare. Chlorophyll content of green leaves was recorded at time flowering by chlorophyll meter. Ascorbic acid content in water spinach was determined by colorimetric method based on the reduction of 2, 6dichlorophenol indophenol by ascorbic acid and was expressed in milligram of ascorbic acid per $100 \mathrm{~g}$ of sample (Ranganna, 2001). Vitamin A content of leaf was estimated by analyzing the beta carotene content of the leaf and dividing the value with 0.6 to obtain the vitamin A content of leaf (Ranganna, 2001). Nitrate content of water spinach leaf was estimated by the method suggested by Cataldo et al. (1975).All the seed quality testing was carried out in the month of May. Shelling percentage was calculated on dry weight basis by dividing the seed weight to the fruit dry weight and multiplied by hundred. Test weight was calculated from threshed seed produce of each plot, 1000 seeds were counted, dried and weights were recorded with the help of microbalance in gram from each plot separately. Germination percentage was estimated following seed germination test method using germination paper (Arya, 1999). The vigour index of seedling was calculated by adopting the method suggested by Abdul Baki and Anderson (1973) and was expressed in whole number. Seedling growth rate (SGR) was calculated according to Amjad and Anjum (2002). Data on different growth, yield, quality and seed quality was recorded from ten selected plants from each plot and analyzed statistically as per method suggested by Gomez and Gomez (1984). The cost of production and gross return estimated on the basis of price fixed by Government of West Bengal to work out the economics of water spinach cultivation in Terai region of West Bengal. The cost of production and gross return estimated on the basis of price fixed by Government of West Bengal to work out the economics of water spinach cultivation in terai region of West Bengal.

\section{RESULTS AND DISCUSSION}

Growth and physiological parameters: In this study, significant differences were recorded among the treatments with respect to different vegetative growth, physiological parameters, green yield and seed yield as well as quality parameters except average internode length of water spinach. However, maximum vine length $(36.56 \mathrm{~cm})$, number of nodes/plant $(18.41)$ and internode length $(1.95 \mathrm{~cm})$ were recorded in $1^{\text {st }}$ week of May $\left(\mathrm{P}_{1}\right)$, while, minimum in $1^{\text {st }}$ week of July $\left(\mathrm{P}_{3}\right)$. This could have been due to the favourable conditions of moisture supply, clear weather condition with optimum temperature throughout this growth period. It was evident that there was an enhancement in these parameters decreased in plant spacing from $30 \mathrm{~cm} \times 45$ $\mathrm{cm}$ to $30 \mathrm{~cm} \times 15 \mathrm{~cm}$ (Table 1). Significantly maximum vine length $(37.23 \mathrm{~cm})$, number of nodes (19.03) and internode length $(2.00 \mathrm{~cm})$ were obtained in closest spacing of $30 \mathrm{~cm} \times 15 \mathrm{~cm}\left(\mathrm{~S}_{1}\right)$. Interaction between sowing time and spacing was found to be significant. The combination of $1^{\text {st }}$ week of May sowing with closest spacing of $30 \mathrm{~cm} \times 15 \mathrm{~cm}\left(\mathrm{P}_{1} \mathrm{~S}_{1}\right)$ gave maximum vine length, number of nodes/plant, internode length $(40.83 \mathrm{~cm}, 20.38$ and $2.04 \mathrm{~cm}$, respectively) whereas, the minimum was recorded in $1^{\text {st }}$ week of July sowing with widest spacing of $30 \mathrm{~cm}$ $\times 45 \mathrm{~cm}\left(\mathrm{P}_{3} \mathrm{~S}_{3}\right)$ The highest plant height recorded in narrow spacing was due to its higher plant density which resulted in greater competition for space, moisture and light and thereby forced the plants to grow taller. These findings are in accordance with the earlier findings of Pandita and Randhawa (1994) who reported that spacing significantly affected plant height in fenugreek.

The results on physiological parameters such as leaf chlorophyll, leaf area index (LAI) and crop growth rate (CGR) of water spinach showed significant variations with different sowing times (Table 1 ). The $1^{\text {st }}$ week of May $\left(\mathrm{P}_{1}\right)$ recorded significantly maximum leaf chlorophyll (40.91 SPAD 502), LAI (1.08) and CGR (5.22 g/ $\mathrm{m}^{2} /$ day), whereas, minimum values in $1^{\text {st }}$ week of July $\left(\mathrm{P}_{3}\right)$. All these parameters except leaf chlorophyll increased with higher plant density. It is therefore, maximum leaf chlorophyll (41.68 SPAD 502) was recorded in widest spacing of $30 \mathrm{~cm} \times 45 \mathrm{~cm}\left(\mathrm{~S}_{3}\right)$, whereas, lowest value (38.59 SPAD 502) at closest spacing of 30 $\mathrm{cm} \times 15 \mathrm{~cm}\left(\mathrm{~S}_{1}\right)$. The higher leaf chlorophyll with higher plant spacing might be due to less competition for nutrients, water etc. because of the low plant popu- 
lation which enhances more photosynthesis. Meena et al. (2011) reported higher leaf chlorophyll in wider spacing which correlates with the present investigation. On the other hand, maximum LAI (1.45) and CGR $\left(7.01 \mathrm{~g} / \mathrm{m}^{2} /\right.$ day $)$ were obtained from closest plant spacing of $30 \mathrm{~cm} \times 15 \mathrm{~cm}\left(\mathrm{~S}_{1}\right)$. Among the interactions, $\mathrm{P}_{1} \mathrm{~S}_{3}$ combination recorded maximum leaf chlorophyll (42.49 SPAD 502) and minimum in $\mathrm{P}_{3} \mathrm{~S}_{1}$ combination. On the contrary, maximum LAI and CGR (1.60 and $7.58 \mathrm{~g} / \mathrm{m}^{2} /$ day), respectively were recorded in combination of $1^{\text {st }}$ week of May with closest spacing of $30 \mathrm{~cm} \times 15 \mathrm{~cm}\left(\mathrm{P}_{1} \mathrm{~S}_{1}\right)$ closely followed by $\mathrm{P}_{2} \mathrm{~S}_{1}$ and $\mathrm{P}_{3} \mathrm{~S}_{1}$ combination and was 3.02 times and 2.78 times, respectively more over $\mathrm{P}_{3} \mathrm{~S}_{3}$ combination which indicated the minimum values ( 0.53 and $2.73 \mathrm{~g} / \mathrm{m}^{2} /$ day), respectively. The higher LAI under closer spacing might be due to accommodation of more plants in per unit area. The increased CGR was due to enhanced LAI at closest spacing because of more plant population per unit area. The LAI of a plant is an indication of its photosynthetic assimilation and translocation. Malligawad and Patil (2001) reported that LAI increased with increasing crop density in amaranthus which are in conformity with present study.

Plant biomass yield per hectare was significantly affected with sowing time (Table 1). Significantly maximum green yield (14.96 t/ha) was recorded in $1^{\text {st }}$ week of May $\left(\mathrm{P}_{1}\right)$ followed by $\mathrm{P}_{2}(13.38 \mathrm{t} / \mathrm{ha})$ and minimum $(8.65 \mathrm{t} / \mathrm{ha})$ in $1^{\text {st }}$ week of July $\left(\mathrm{P}_{3}\right)$. A significant increase in green yield per hectare was found with closer spacing. Maximum green yield $(15.82 \mathrm{t} / \mathrm{ha})$ was produced at closest spacing of $30 \mathrm{~cm}$ $\times 15 \mathrm{~cm}\left(\mathrm{~S}_{1}\right)$ followed by $30 \mathrm{~cm} \times 30 \mathrm{~cm}\left(\mathrm{~S}_{2}\right)$ and the minimum $(8.28 \mathrm{t} / \mathrm{ha})$ in widest spacing of $30 \mathrm{~cm} \times 45$ $\mathrm{cm}\left(\mathrm{S}_{3}\right)$. Comparatively combination between $1^{\text {st }}$ week of May with $30 \mathrm{~cm} \times 15 \mathrm{~cm}$ spacing $\left(\mathrm{P}_{1} \mathrm{~S}_{1}\right)$ recorded maximum green yield (18.83 t/ha), the second highest (17.09 t/ha) and minimum (5.79 t/ha) in combination of $1^{\text {st }}$ week of July with $30 \mathrm{~cm} \times 45$ $\mathrm{cm}$ spacing $\left(\mathrm{P}_{3} \mathrm{~S}_{3}\right)$. The green yield of water spinach increased with higher planting densities and was highest at the highest planting density or closest spacing. This was probably due to increase in the

Table 1. Effect of sowing times and spacings on growth, physiological, green yield and its quality parameters of water spinach (pooled).

\begin{tabular}{|c|c|c|c|c|c|c|c|c|c|c|}
\hline Treatment & $\begin{array}{c}\text { Vine } \\
\text { length } \\
\text { (cm) }\end{array}$ & $\begin{array}{c}\text { No. of } \\
\text { nodes / } \\
\text { plant }\end{array}$ & $\begin{array}{l}\text { Internode } \\
\text { length } \\
\text { (cm) }\end{array}$ & $\begin{array}{c}\text { Leaf } \\
\text { Area } \\
\text { Index }\end{array}$ & $\begin{array}{c}\text { Crop } \\
\text { Growth } \\
\text { Rate }\end{array}$ & $\begin{array}{l}\text { Chlorophyll } \\
\text { content } \\
\text { (SPAD 502) }\end{array}$ & $\begin{array}{l}\text { Green } \\
\text { yield } \\
(\mathrm{t} / \mathrm{ha})\end{array}$ & $\begin{array}{c}\text { Ascorbic } \\
\text { acid } \\
(\mathrm{mg} / \mathbf{1 0 0 g})\end{array}$ & $\begin{array}{c}\text { Vitamin } \\
\text { A } \\
(\mu \mathrm{g} / \mathbf{1 0 0 g})\end{array}$ & $\begin{array}{l}\text { Nitrate } \\
\text { content } \\
(\mathrm{mg} / \mathrm{kg})\end{array}$ \\
\hline \multicolumn{11}{|l|}{ Sowing `time } \\
\hline $\mathrm{P}_{1}$ & 36.56 & 18.41 & 1.95 & 1.08 & 5.22 & 40.91 & 14.96 & 41.10 & 2846.0 & 375.4 \\
\hline $\mathrm{P}_{2}$ & 33.20 & 17.83 & 1.92 & 0.98 & 4.76 & 39.92 & 13.38 & 42.31 & 2954.7 & 388.9 \\
\hline $\mathrm{P}_{3}$ & 29.70 & 16.57 & 1.86 & 0.89 & 4.54 & 39.44 & 8.65 & 39.73 & 2812.6 & 384.2 \\
\hline S. Em \pm & 0.43 & 0.20 & 0.01 & 0.02 & 0.10 & 0.34 & 0.26 & 0.28 & 28.1 & 4.4 \\
\hline C.D. at $5 \%$ & 1.23 & 0.59 & NS & 0.10 & 0.28 & 0.97 & 0.74 & 0.79 & 80.2 & 12.7 \\
\hline \multicolumn{11}{|l|}{ Spacing } \\
\hline $\mathrm{S}_{1}$ & 37.23 & 19.03 & 2.00 & 1.45 & 7.01 & 38.59 & 15.82 & 39.47 & 2815.5 & 371.7 \\
\hline $\mathrm{S}_{2}$ & 32.26 & 17.76 & 1.92 & 0.92 & 4.48 & 40.00 & 12.89 & 40.95 & 2860.1 & 381.7 \\
\hline $\mathrm{S}_{3}$ & 29.97 & 16.01 & 1.81 & 0.58 & 3.02 & 41.68 & 8.28 & 42.71 & 2937.7 & 395.1 \\
\hline S. Em \pm & 0.43 & 0.20 & 0.01 & 0.02 & 0.10 & 0.34 & 0.26 & 0.28 & 28.1 & 4.4 \\
\hline C.D. at $5 \%$ & 1.23 & 0.59 & 0.02 & 0.10 & 0.28 & 0.97 & 0.74 & 0.79 & 80.2 & 12.7 \\
\hline \multicolumn{11}{|c|}{ Interaction (P X S) } \\
\hline $\mathrm{P}_{1} \mathrm{~S}_{1}$ & 40.83 & 20.38 & 2.04 & 1.60 & 7.58 & 39.36 & 18.83 & 39.77 & 2773.2 & 363.3 \\
\hline $\mathrm{P}_{2} \mathrm{~S}_{1}$ & 37.40 & 19.26 & 2.04 & 1.43 & 6.86 & 38.45 & 17.09 & 40.43 & 2920.0 & 378.5 \\
\hline $\mathrm{P}_{3} \mathrm{~S}_{1}$ & 33.47 & 17.45 & 1.91 & 1.32 & 6.59 & 37.95 & 11.53 & 38.22 & 2752.7 & 373.2 \\
\hline $\mathrm{P}_{1} \mathrm{~S}_{2}$ & 35.66 & 18.70 & 1.98 & 1.00 & 4.74 & 40.87 & 15.69 & 41.24 & 2826.2 & 375.0 \\
\hline $\mathrm{P}_{2} \mathrm{~S}_{2}$ & 32.12 & 17.89 & 1.90 & 0.92 & 4.41 & 39.88 & 14.36 & 42.41 & 2952.1 & 386.7 \\
\hline $\mathrm{P}_{3} \mathrm{~S}_{2}$ & 29.00 & 16.70 & 1.87 & 0.83 & 4.29 & 39.25 & 8.63 & 39.21 & 2802.1 & 383.5 \\
\hline $\mathrm{P}_{1} \mathrm{~S}_{3}$ & 33.20 & 16.15 & 1.82 & 0.64 & 3.33 & 42.49 & 10.36 & 42.28 & 2938.1 & 387.8 \\
\hline $\mathrm{P}_{2} \mathrm{~S}_{3}$ & 30.08 & 16.34 & 1.82 & 0.58 & 3.01 & 41.43 & 8.68 & 44.10 & 2992.0 & 401.5 \\
\hline $\mathrm{P}_{3} \mathrm{~S}_{3}$ & 26.62 & 15.55 & 1.80 & 0.53 & 2.73 & 41.12 & 5.79 & 41.75 & 2883.0 & 396.0 \\
\hline S. Em \pm & 0.74 & 0.35 & 0.01 & 0.04 & 0.17 & 0.59 & 0.45 & 0.48 & 48.6 & 7.7 \\
\hline C.D. at $5 \%$ & 2.13 & 0.99 & 0.03 & 0.12 & 0.48 & 1.68 & 1.28 & 1.37 & 138.9 & 22.0 \\
\hline
\end{tabular}

SEm-Standard error of the mean; CD-critical difference; Treatments: sowing time- $\mathrm{P}_{1}, 1^{\text {st }}$ week of May; $\mathrm{P}_{2}, 1^{\text {st }}$ week of June; $\mathrm{P}_{3}$, $1^{\text {st }}$ week of July and spacing- $\mathrm{S}_{1}, 30 \mathrm{~cm} \times 15 \mathrm{~cm} ; \mathrm{S}_{2}, 30 \mathrm{~cm} \times 30 \mathrm{~cm} ; \mathrm{S}_{3}, 30 \mathrm{~cm} \times 45 \mathrm{~cm}$. 
Table 2. Effect of sowing times and spacings on seed yield and its quality parameters of water spinach (pooled).

\begin{tabular}{|c|c|c|c|c|c|c|c|c|}
\hline Treatment & $\begin{array}{l}\text { No. of } \\
\text { flowers } \\
\text { /hill }\end{array}$ & $\begin{array}{c}\text { No. of } \\
\text { capsules } \\
\text { /hill }\end{array}$ & $\begin{array}{c}\text { Seed yield } \\
(\mathrm{t} / \mathrm{ha})\end{array}$ & $\begin{array}{c}\text { Shelling } \\
\text { percent } \\
(\%)\end{array}$ & $\begin{array}{l}1000 \text { seed } \\
\text { weight }(\mathrm{g})\end{array}$ & $\begin{array}{c}\text { Germination } \\
\text { percent }\end{array}$ & $\begin{array}{l}\text { Seedling } \\
\text { vigour } \\
\text { index }\end{array}$ & $\begin{array}{c}\text { Seedling } \\
\text { growth } \\
\text { rate }\end{array}$ \\
\hline \multicolumn{9}{|l|}{ Sowing time } \\
\hline $\mathrm{P}_{1}$ & 200.1 & 146.2 & 0.65 & 56.73 & 38.18 & $79.40(8.90)$ & 4.71 & 0.073 \\
\hline $\mathrm{P}_{2}$ & 218.9 & 160.2 & 0.70 & 59.85 & 38.97 & $80.13(8.95)$ & 4.97 & 0.076 \\
\hline $\mathrm{P}_{3}$ & 191.0 & 137.1 & 0.60 & 54.16 & 38.12 & $76.40(8.74)$ & 4.57 & 0.067 \\
\hline S. Em \pm & 0.74 & 0.59 & 0.01 & 0.45 & 0.44 & 0.34 & 0.07 & 0.001 \\
\hline C.D. at $5 \%$ & 2.12 & 1.68 & 0.02 & 1.29 & NS & 0.98 & 0.20 & 0.003 \\
\hline \multicolumn{9}{|l|}{ Spacing } \\
\hline $\mathrm{S}_{1}$ & 188.8 & 132.6 & 0.73 & 53.97 & 36.41 & $76.30(8.73)$ & 4.13 & 0.061 \\
\hline $\mathrm{S}_{2}$ & 203.1 & 147.3 & 0.65 & 56.67 & 38.94 & $78.77(8.88)$ & 4.87 & 0.071 \\
\hline $\mathrm{S}_{3}$ & 218.0 & 163.6 & 0.56 & 60.09 & 39.92 & $80.87(8.99)$ & 5.25 & 0.083 \\
\hline S. Em \pm & 0.74 & 0.59 & 0.01 & 0.45 & 0.44 & 0.34 & 0.07 & 0.001 \\
\hline C.D. at $5 \%$ & 2.12 & 1.68 & 0.02 & 1.29 & 1.26 & 0.98 & 0.20 & 0.003 \\
\hline \multicolumn{9}{|c|}{ Interaction (P X S) } \\
\hline $\mathrm{P}_{1} \mathrm{~S}_{1}$ & 190.6 & 133.6 & 0.73 & 53.66 & 36.23 & 76.90 & 3.99 & 0.061 \\
\hline $\mathrm{P}_{2} \mathrm{~S}_{1}$ & 201.8 & 142.5 & 0.78 & 57.62 & 37.14 & 78.10 & 4.51 & 0.063 \\
\hline $\mathrm{P}_{3} \mathrm{~S}_{1}$ & 174.1 & 121.8 & 0.69 & 50.63 & 36.58 & 73.90 & 3.90 & 0.059 \\
\hline $\mathrm{P}_{1} \mathrm{~S}_{2}$ & 201.5 & 146.8 & 0.66 & 55.90 & 38.69 & 79.40 & 4.91 & 0.071 \\
\hline $\mathrm{P}_{2} \mathrm{~S}_{2}$ & 218.0 & 158.5 & 0.69 & 59.39 & 39.21 & 79.90 & 5.02 & 0.075 \\
\hline $\mathrm{P}_{3} \mathrm{~S}_{2}$ & 189.9 & 136.6 & 0.61 & 54.73 & 38.92 & 77.00 & 4.69 & 0.068 \\
\hline $\mathrm{P}_{1} \mathrm{~S}_{3}$ & 208.2 & 158.2 & 0.55 & 60.62 & 39.62 & 81.90 & 5.23 & 0.089 \\
\hline $\mathrm{P}_{2} \mathrm{~S}_{3}$ & 237.0 & 179.7 & 0.63 & 62.53 & 40.56 & 82.40 & 5.38 & 0.091 \\
\hline $\mathrm{P}_{3} \mathrm{~S}_{3}$ & 208.9 & 152.9 & 0.51 & 57.12 & 39.57 & 78.30 & 5.13 & 0.073 \\
\hline S. Em \pm & 1.29 & 1.02 & 0.01 & 0.78 & 0.76 & 0.60 & 0.12 & 0.002 \\
\hline C.D. at 5\% & 3.68 & 2.92 & 0.03 & 2.24 & 2.18 & 1.70 & 0.35 & 0.005 \\
\hline
\end{tabular}

SEm-Standard error of the mean; CD-critical difference; Treatments: sowing time- $\mathrm{P}_{1}, 1^{\text {st }}$ week of May; $\mathrm{P}_{2}, 1^{\text {st }}$ week of June; $\mathrm{P}_{3}, 1^{\text {st }}$ week of July and spacing- $\mathrm{S}_{1}, 30 \mathrm{~cm} \times 15 \mathrm{~cm} ; \mathrm{S}_{2}, 30 \mathrm{~cm} \times 30 \mathrm{~cm} ; \mathrm{S}_{3}, 30 \mathrm{~cm} \times 45 \mathrm{~cm}$.

number of plants per unit area in closer spacing, which might contribute to the production of extra leaf yield per unit area leading to high biomass yield. The present study was in accordance with the findings of Nashrin et al. (2002) who reported highest green yield obtained at closest spacing in water spinach.

Quality parameter of water spinach: There were highly significant effects due to different sowing times regarding ascorbic acid, vitamin A and leaf nitrate of water spinach (Table 2). Maximum ascorbic acid $(42.31 \mathrm{mg} / 100 \mathrm{~g})$, vitamin A $(2954.7 \mu \mathrm{g} / 100 \mathrm{~g})$ and leaf nitrate $(388.9 \mathrm{mg} / \mathrm{kg})$ was recorded in $1^{\text {st }}$ week of June $\left(\mathrm{P}_{2}\right)$ and minimum in $1^{\text {st }}$ week July under $\left(\mathrm{P}_{3}\right)$ except leaf nitrate was found minimum in $1^{\text {st }}$ week of May $\left(\mathrm{P}_{1}\right)$. These attributes were gradually increased with higher spacing. Significantly maximum (42.71 $\mathrm{mg} / 100 \mathrm{~g}, 2937.7 \mu \mathrm{g} / 100 \mathrm{~g}$ and $395.1 \mathrm{mg} / \mathrm{kg}$ ), respectively were accumulated in widest spacing of 30 $\mathrm{cm} \times 45 \mathrm{~cm}\left(\mathrm{~S}_{3}\right)$ as against minimum $(39.47 \mathrm{mg} / 100 \mathrm{~g}$, $2815.5 \mu \mathrm{g} / 100 \mathrm{~g}$ and $371.7 \mathrm{mg} / \mathrm{kg}$ ) at closest spacing of $30 \mathrm{~cm} \times 15 \mathrm{~cm}\left(\mathrm{~S}_{1}\right)$. Krezel and Kolota (2003) reported that ascorbic acid significantly influenced by sowing dates in Chinese cabbage. The increase in all parameters of water spinach leaves in wider spacing might be due to less competition for nutrient because of low plant population per unit area which causes more protein synthesis in leaves resulting higher carotene. The increase in all parameters of water spinach leaves in wider spacing might be due to less competition for nutrient because of low plant population per unit area which causes more protein synthesis in leaves resulting higher carotene. The interaction between sowing time and spacing was also found to be significant with respect to green quality. These were recorded to be maximum $(44.10 \mathrm{mg} / 100 \mathrm{~g}$, $2992.0 \mu \mathrm{g} / 100 \mathrm{~g}$ and $401.5 \mathrm{mg} / \mathrm{kg}$ ) in $1^{\text {st }}$ week of June with widest spacing of $30 \mathrm{~cm} \times 45 \mathrm{~cm}\left(\mathrm{P}_{2} \mathrm{~S}_{3}\right)$ which was very closely followed by $\mathrm{P}_{2} \mathrm{~S}_{2}, \mathrm{P}_{1} \mathrm{~S}_{3}$ and $\mathrm{P}_{3} \mathrm{~S}_{3}$ combinations and minimum (38.22 g/100 and 2752.7 $\mu \mathrm{g} / 100 \mathrm{~g}$ ), respectively in $\mathrm{P}_{3} \mathrm{~S}_{1}$ combination but leaf nitrate was minimum $(363.3 \mathrm{mg} / \mathrm{kg})$ in $\mathrm{P}_{1} \mathrm{~S}_{1}$ combination. Naik and Gupta (2010) and Mujahid and Gupta (2010) recorded maximum ascorbic acid and total carotenoid content with wider spacing in kale and 
lettuce, respectively which are in good connection with the present investigation. The higher leaf nitrate concentration of water spinach was recorded in widest spacing might be due to more nutrient absorption from soil because of less plant population per unit area which causes more nitrate accumulation in leaves.

The number of flower and number of capsules per hill were positively influenced by different sowing time and spacing. The $1^{\text {st }}$ week of June $\left(\mathrm{P}_{2}\right)$ produced maximum number of flowers/hill (218.9) and number of capsules/hill (160.2), while, least number of both these parameters (191.0 and 137.1), respectively was found when crop was sown in $1^{\text {st }}$ week of July $\left(\mathrm{P}_{3}\right)$. Significant improvement in these two attributes was attained with an increase in spacing. It is believed that wider spacing provided sufficient space and less competition between available nutrients for plants. Therefore, there was increase in number of flowers and number of capsules per hill. Interaction between sowing time and spacing was found statistically significant over number of flowers and number of capsules

Seed yield: The seed yield was significantly affected by sowing times (Table 2). Significantly highest seed yield $(0.70 \mathrm{t} / \mathrm{ha})$ was produced by the plots sown in $1^{\text {st }}$ week of June $\left(\mathrm{P}_{2}\right)$ followed by $\mathrm{P}_{1}(0.65 \mathrm{t} / \mathrm{ha})$ and it was 16.67 percent higher over $1^{\text {st }}$ week of July $(0.60 \mathrm{t} / \mathrm{ha})$. The higher seed yield in $1^{\text {st }}$ week of June $\left(\mathrm{P}_{2}\right)$ might be due to favorable weather condition which results better vegetative growth, more retention of flowers and capsules per hill. The spacing had positive correlation with respect to this attribute. It was decreased linearly with higher plant spacing. Highest seed yield $(0.73 \mathrm{t} /$ ha) was recorded at closer spacing of $30 \mathrm{~cm} \times 15 \mathrm{~cm}$ $\left(\mathrm{S}_{1}\right)$ and lowest $(0.56 \mathrm{t} / \mathrm{ha})$ at widest spacing of $30 \mathrm{~cm}$ $\times 45 \mathrm{~cm}\left(\mathrm{~S}_{3}\right)$. The combination of $1^{\text {st }}$ week of June with $30 \mathrm{~cm} \times 15 \mathrm{~cm}\left(\mathrm{P}_{2} \mathrm{~S}_{1}\right)$ produced significantly highest seed yield (0.78 t/ha), the second highest was observed in $\mathrm{P}_{1} \mathrm{~S}_{1}$ combination $(0.73 \mathrm{t} / \mathrm{ha})$ and lowest value of $0.51 \mathrm{t} / \mathrm{ha}$ in $1^{\text {st }}$ week of July with $30 \mathrm{~cm} \times 45 \mathrm{~cm}$ spacing $\left(\mathrm{P}_{3} \mathrm{~S}_{3}\right)$. Yadav et al. (1994) reported that closest spacing registered significantly higher seed yield than wider spacing in mustard which are in conformity with the present investigation.

Seed quality parameters: All seed quality parameters viz. shelling percentage, germination percentage, seed vigour index (SVI) and seedling growth rate were significantly responded due to sowing time except 1000 seed weight (Table 2). However, highest 1000 seed weight of $38.97 \mathrm{~g}$ was recorded in $1^{\text {st }}$ week of June $\left(\mathrm{P}_{2}\right)$. Besides, significantly highest shelling percentage (59.85), germination percentage (80.13), SVI (4.97) and seedling growth rate $(0.076 \mathrm{~g} / \mathrm{plant} /$ day) were recorded in $1^{\text {st }}$ week of June $\left(\mathrm{P}_{2}\right)$. This was statistically at par with $1^{\text {st }}$ week of May $\left(\mathrm{P}_{1}\right)$ with respect to all above seed quality attributes. These seed quality parameters were reported to be lowest at last sowing on $1^{\text {st }}$ week of July $\left(\mathrm{P}_{3}\right)$. The plant spacing positively affected these seed quality attributes of water spinach. Chaudhari et al. (1995) also reported significant effects due to sowing date on seed quality parameters of coriander. There was an increasing trend in all these attributes with higher spacing. Therefore, widest spacing of $30 \mathrm{~cm} \times 45 \mathrm{~cm}\left(\mathrm{~S}_{3}\right)$ significantly recorded highest shelling percentage (60.09), 1000 seed weight (39.92 g), germination percentage (80.87), SVI (5.25) and seedling growth rate $(0.083 \mathrm{~g} / \mathrm{plant} /$ day), whereas, all these were found to be lowest at closest spacing of $30 \mathrm{~cm} \times 15 \mathrm{~cm}\left(\mathrm{~S}_{1}\right)$. The interaction $\mathrm{P}_{2} \mathrm{~S}_{3}$ recorded superior quality seed $(62.53 \%, 40.56 \mathrm{~g}$, $82.40 \%, 5.38$ and $0.091 \mathrm{~g} / \mathrm{plant} /$ day), respectively in respect of all these quality attributes, while, poor quality seed were produced in $\mathrm{P}_{3} \mathrm{~S}_{1}$ combination. The better quality seed of water spinach with greater plant spacing might be due to the availability of more area, moisture, nutrient etc. per plant which might have resulted in development of bold seeds. The present findings with respect to seed quality attributes were in accordance with observations reported by Anilkumar (2004) who recorded that 1000 seed weight, germination percentage and SVI of fenugreek were found to be better at wider spacing compared to narrow spacing.

Benefit cost ratio: The economics of production for water spinach cultivation with varied sowing dates and spacing showed variations among treatment combinations on gross return, net return and benefit cost ratio (BCR). The $\mathrm{P}_{1} \mathrm{~S}_{1}$ combination recorded maximum gross return (Rs. 16,0328.00), highest net return (Rs. 109124.00) as well as higher B:C ratio (2.13). This was followed by $\mathrm{P}_{2} \mathrm{~S}_{1}$ combination with $\mathrm{B}: \mathrm{C}$ ratio of 2.12), while, combination $\mathrm{P}_{3} \mathrm{~S}_{3}$ recorded lowest gross return (Rs. 80708.00) and net return (Rs. $31255.00)$ and $\mathrm{B}: \mathrm{C}$ ratio (0.63) amongst all the treatments combinations.

\section{Conclusion}

From the above discussion it may be concluded that on economic point of view, the combination of $1^{\text {st }}$ week of May along with $30 \mathrm{~cm} \mathrm{X} 15 \mathrm{~cm}$ spacing was noticed to be superior amongst all other remaining treatment combination with respect to growth, yield, quality and economic point of view and that may be adopted for its commercial cultivation in medium to upland situation under tarai region of West Bengal.

\section{REFERENCES}

Abdul Baki, A. A. and Anderson, J. D. (1973). Vigour determination in soybean seeds multiple criteria. Crop Science, 13: 630-633.

Amjad, M. and Anjum, M. A. (2002). Evaluation of physiological quality of onion seed stored for different periods. International Journal of Agriculture and Biology, 4:365-369.

Anilkumar, (2004). Standardization of seed production techniques in fenugreek (Trigonella foenum graecum L.). M.Sc. (Agri) Thesis, University of Agricultural Sciences, Dharwad.

Arya, P. S. (1999). Vegetable seed production principles. Kalyani Publishers, Ludhiana, India, pp. 195-207. 
Cataldo, D. A., Maroon, M., Schrader, L. E. and Youngs, V. L. (1975). Rapid colorimetric determination of nitrate in plant tissue by nitration of salicylic acid. Soil Science and Plant Analysis, 6(1): 71-80.

Chaudhari, S. M, Kharche, S. M. and Desai, U. T. (1995). Effects of sowing dates on seed production in coriander. Journal of Maharashtra Agricultural Universities, 20(1): 139.

Gomez, K. A. and Gomez, A. A. (1984). Statistical Procedures in Agricultural Research, John Wiley and sons $\left(2^{\text {nd }} \mathrm{Ed}\right)$. New York. pp. 680

Krezel, J. and Kolota, E. (2003). Yield evaluation of some chinese cabbage cultivars in spring and autumn cultivation. Folia Horticulturae, 15(1): 11-18.

Malligawad, L. H. and Patil, V. C. (2001). Effect of plant density and planting geometry on growth and yield of grain amaranths. Karnataka Journal of Agricultural Sciences, 14(1): 11-17.

Meena, B. P., Kumawat, S. M. and Yadav, R. S. (2011). Effect of planting geometry and nitrogen management on groundnut (Arachis hypogea) in loamy sand soil of Rajasthan. Indian Journal of Agricultural sciences, 81 (1): 86-88.

Mujahid, A. M. and Gupta, A. J. (2010). Effect of plant spacing, organic manure and inorganic fertilizer and their combination on growth, yield and quality of lettuce (Lactuca sativa). Indian Journal of Agricultural Science, 80(2): 177-181.

Naik, I. A. and Gupta, J. (2010). Effect of planting density and integrated nutrient management on growth, yield, quality and economics of kale (Brassica oleracea var. acephale) in temperate region. Indian Journal of Agricultural Sciences, 80(1): 81-84.

Nashrin, S. A., Farooque, A. M., Siddiqua, M. K., Rahman, M. M. and Khanm, M. R. (2002). Effect of nitrogen and spacing on the growth and yield of Gimakalmi (Ipomoea reptans Poir.). Journal of Biological Sciences, 2(3): 170-174.

Palada, M. C. and Crossman, S. M. A. (1998). Planting density affects growth and yield of bush okra (Corchorus olitorius). Proceedings of 34th Annual Meeting 1998 - Caribbean Food Crop Society, pp. 52-57

Pandita, U. K. and Randhawa, K. S. (1994). Row spacing and leaf cutting in relation to seed production of fenugreek. Seed Research, 22(2): 122-129.

Ranganna, S. (2001). Analysis and quality control for fruits and vegetable products. Tata $\mathrm{Mc}$ Grawhill Publication. $2^{\text {nd }}$ Edition, New Delhi, pp 110-112.

Sarkar, R. (2012). Response of different agro-techniques on growth, yield and quality of water spinach (Ipomoea reptans Poir.). Ph.D. Thesis, Submitted in the Uttar Banga Krishi Viswavidyalaya, Pundibari, Cooch Behar, West Bengal, India.

Thacker, P. A. (1990) Alfalfa meal. In: Nontraditional Feed Sources for Use in Swine Production (Editors: P. A. Thacker and R. A. Kirkwood). Butterworths, London, pp 6-9.

Yadav, R. N., Suraj, B. and Uttam, S. K. (1994). Yield and moisture use efficiency of mustard in relation to sowing date. Variety and spacing in rainfed lands of Central Uttar Pradesh. Indian Journal of Soil Conservations, 22(3): 20-29. 